\title{
Article
}

\section{Up the ANTe: Understanding Entrepreneurial Leadership Learning through Actor-network Theory}

Smith, Susan, Kempster, Steve and Barnes, Stewart

Available at http://clok.uclan.ac.uk/16750/

Smith, Susan ORCID: 0000-0002-3152-2149, Kempster, Steve and Barnes, Stewart (2017) Up the ANTe: Understanding Entrepreneurial Leadership Learning through Actor-network Theory. Industry and Higher Education, 31

(2). pp. 132-139. ISSN 0950-4222

It is advisable to refer to the publisher's version if you intend to cite from the work. http://dx.doi.org/10.1177/0950422217691667

For more information about UCLan's research in this area go to http://www.uclan.ac.uk/researchgroups/ and search for <name of research Group>.

For information about Research generally at UCLan please go to http://www.uclan.ac.uk/research/

All outputs in CLoK are protected by Intellectual Property Rights law, including Copyright law. Copyright, IPR and Moral Rights for the works on this site are retained by the individual authors and/or other copyright owners. Terms and conditions for use of this material are defined in the policies page.

\section{CLoK}

Central Lancashire online Knowledge www.clok.uclan.ac.uk

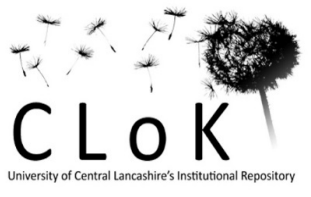


Up the ANTe: Understanding Entrepreneurial Leadership Learning through Actornetwork Theory

\author{
Authors: \\ Professor Sue Smith (corresponding author) \\ Director for the Centre of SME Development \\ University of Central Lancashire \\ Preston \\ Lancashire \\ PR1 2HE \\ Mob: 07834178493 \\ E: ssmith35@uclan.ac.uk \\ Professor Steve Kempster \\ Director of Lancaster Leadership Centre \\ Lancaster University \\ Stewart Barnes \\ Founder and Managing Director \\ QuoLux Ltd
}




\title{
Up the ANTe: Understanding Entrepreneurial Leadership Learning through Actor- network Theory
}

\begin{abstract}
This paper explores the role of educators in supporting the development of entrepreneurial leadership learning though creating peer learning networks of owner-managers of small businesses. Using actor-network theory as a lens we think through the process of constructing and maintaining a peer learning network (conceived of as an actor-network) and frame entrepreneurial leadership learning as a network effect. Our paper is of significance to theory and practice in terms of understanding the dynamics, challenges and opportunities surrounding the construction and ongoing maintenance of networks and how to stimulate entrepreneurial leadership learning.
\end{abstract}

\section{Keywords: entrepreneurial leadership learning, SMEs, actor-network theory}

\section{Introduction}

This paper is concerned with the entrepreneurial leadership learning of owner-managers of Small and medium sized enterprises (SMEs) and the role educators play in developing this through peer learning networks. It is broadly accepted that leadership learning occurs through the milieu of lived experience (Davies and Easterby-Smith, 1984; Cox and Cooper, 1989; Jansen, 2008; Kempster, 2006; McCall, 2004). However, SME owner-managers are constrained by the very context that makes them a leader, i.e. their business (see Kempster and Cope, 2010 and Barnes et al, 2015). We use the term 'entrepreneurial leadership learning' (ELL) to mean leadership learning in the small business / entrepreneurial context, i.e. how the owner-manager (or leader of the SME) learns leadership. The literature that addresses ELL (see for example, Vecchio, 2003; Surie and Ashley, 2008; Bagheri and Pihie, 2011) shows that the 
definition is not significantly different to the debates in the leadership field. Leadership is generally considered to be a situated and relational process of influence oriented toward goals, directions, purposes, vision (for a useful review see Drath,et al, 2008).

Kempster and Cope (2010) show how the entrepreneurial context has a marked impact on ELL; in many ways the entrepreneurial context stifles leadership learning. This does not mean the entrepreneur is not leading - far from it. Their leadership has a very powerful impact on their employees and the business. Rather, the context limits the stimuli of leadership learning. The outcome is often a form of leadership that draws heavily on early formative experiences most notably the familial, educational and first employment context. In essence 'the small business is the dominant situated crucible in which entrepreneurs learn to lead... [the] relationship between the entrepreneur and his/her business reflects a reinforcing and arguably limiting situation with regard to [entrepreneurial] leadership learning' (Kempster and Cope, 2010: 21-22). Further, Kempster and Cope (2010) highlight that their research showed the employed senior managers had an extensive variety of roles and variety of contexts in which to practice their leading (highlighted earlier in Davies and Easterby-Smith, 1984; and with McCall et al, 1988) and such variety gave access to an increasing variety of notable people to observe. In contrast owner-managers often described a limited range of contexts and a restricted tenure in employment. For the employed managers the tenure and longevity was significant; it led to ever increasing sense of identification with leadership (DeRue and Ashford, 2010). At the same time leadership became more salient - they were observing the phenomenon of leadership with ever greater attention. This salience and identification with leadership was significantly less with owner-managers.

It is recognised that developing the leadership capability of the owner-manager(s) of SMEs can lead to business growth. Empirical studies have shown this to be the case (see Wren and Jones 2006, 2012; Jones et al, 2012; Henley, 2012). Bosworth, Davies and Wilson (2002, 
p. 8) state one of the fundamental problems holding back the growth of SMEs is a lack of leadership and management capability to drive performance and enable them to succeed. Successive government schemes have focused on SME growth through leadership development support but within the UK there is much to do in this arena as highlighted by Smallbone et al, (2015). This paper responds to this through focusing on an innovative form of ELL through the creation of a peer learning network of SMEs. Our inquiry explores the role of the educator in developing specific opportunities to increase the salience of leadership for owner-managers to enable ELL. This research contributes to both theory and practice. We use actor-network theory (ANT) as a theoretical framework for understanding the process of constructing and maintaining peer learning network to enable ELL, in doing so, we push the boundaries of actor-network into its embryonic use as a learning theory. We intend our research to inform the practice of peer learning networks in order to help SME owner-managers develop ELL which can lead to economic growth. To this end, we offer practical insights into the role of the educator and, in actor-network terms, the role of 'non-humans' in building and maintaining peer learning networks of SMEs for the purpose of developing ELL.

The paper is structured as follows. We outline the context of the study through the methodology and our qualitative, ethnographic approach. Because we use ANT as an analytical tool and a theoretical framework to explain the role of the educator in building and maintaining the learning network, we give a detailed overview of the theory and how it has been applied in this context. This leads us to present two aesthetic narratives to bring to life the data, followed by an ANT reading of the construction and maintenance of a peer learning network. In doing so we show how ELL is a network effect. We close by discussing the limitations of our approach alongside possible opportunities. 


\section{Methodology}

Our research inquiry is centred on exploring the role of educators in developing ELL through peer learning networks. The phenomenon studied in this paper is the LEAD programme and variations of it. In 2004, LEAD was created by a university in the Northwest of England in response to a Government initiative to address the lack of leadership provision for SMEs. As such, a pilot programme was designed underpinned with a participative pedagogy to enable leadership learning in a way that was appropriate for small business owner-managers (see Smith, 2011, Gordon et al, 2010) which drew on the idea that learning is situated or embedded within activity. The activity for the delegates on the programme was their own work practices as owner-managers of SMEs. In other words the learning they experienced as a result of LEAD was situated back into their own contexts. The pedagogy was based on constructionist views of knowledge which required the delegates to engage with the programme and to develop skills and capabilities relevant to their own situations back in their businesses. The circulation of knowledge within LEAD came largely from the delegates and their experiences of running small businesses. This pedagogy included learnerdirected styles of learning and interactive approaches for the delegates to learn from each other and the knowledge they had about running small businesses.

LEAD and derivative programmes with different name continues today ${ }^{1}$. Over the past 11 years, LEAD has been moulded by an ongoing research-led approach and informed also by the delivery and input from the delegates themselves. It has been delivered across England and Wales by Higher Education Institutions, Further Education Colleges and private training companies to nearly 3,000 SMEs. Whilst each provider delivers a nuanced version of the original programme, the learning principles are constant and incorporate a combination of delivery interventions including: masterclasses or think tanks, experiential events, action

\footnotetext{
${ }^{1}$ For the purpose of this paper, these programmes will generically be referred to as 'LEAD'. Other programme names include 'Lancaster LEAD', 'LEAD Wales', 'Leading Growth'
} 
learning, coaching and mentoring, business shadowing and exchanges, site visits to larger companies and reflective learning sessions. Most programmes also offer a virtual learning environment. The programme is delivered in cohorts of between $8-28$ SME owner-managers (or key decision makers) across sectors and takes place over 10 - 12 months.

Our research inquiry was to explore ELL through understanding the construction of a peer learning community of SME owner-managers. Specifically, we ask, what is the role of the educator in ELL? The research question builds from an ontological assumption that knowledge and learning are social constructions. Merriam and Associates (2002) note that the key to understanding qualitative research lies with the idea that meaning is socially constructed by individuals in interaction with their world; "all qualitative research is interested in how meaning is constructed, how people make sense of their lives and their worlds. The primary goal of a basic qualitative study is to uncover and interpret these meanings" (Merriam and Associates, 2002, p. 39, emphasis in the original). Accordingly, we argue that an in-depth qualitative approach was needed to explore the research inquiry. From this perspective we wanted to gain a deeper understanding of the processes within LEAD. Edwards (2005, p. 58) argues: "...if we want to understand learning through participation in practices, we need to examine the practices and what they represent, allow and constrain together with the interactions that occur within them. If we do this, we will get a purchase on what individuals are bringing to these interactions and how they adapt as they engage in practices." To understand the practices, we adopted an ethnographic approach. A total of four different cohorts were studied across three different providers of LEAD over the duration of the different programmes, totalling 81 owner-managers of SMEs. An in depth ethnography was conducted with one cohort (with a university educator). Two further cohorts (with a private training company) and one (with another university) were also researched using an ethnographic approach but were not as intensely followed as the first cohort. 
Ethnography draws heavily on observational methods. Undertaking participant observation was achieved through a number of means. We followed the LEAD delegates into as many situations as possible where and when they experienced LEAD. Our observations were overt and we gained permission from all the delegates to for us to use their cohort for our research. After each observation we ensured we typed up our notes into more comprehensive sentences and accounts of what we had just observed in order to present what Geertz (1973) terms "thick description". We made sure that we did this as soon as possible so as to keep the accounts as fresh as possible. Our research was also made up of many other valuable data. During the participant observations we regularly had conversations with the delegates during the breaks or after the session. Some of these conversations were naturalistic and others were more akin to ad-hoc mini interviews which may resonate with Burgess' (1984) "conversations with a purpose". Certainly, they were not formal, planned qualitative interviews. At times we asked delegates to explain further their actions or reflect on what we had just observed.

We also complemented our observations with other forms of data such as emails from the delegates, posts on the virtual learning environment, our own reflections, slides from the taught elements and posters and other materials that the delegates created from the sessions. These were all gathered and typed up into an electronic form of an ethnographic diary.

We occupied a dual role of being educators and researchers and thus were not separated or independent from the delegates' experiences. Easterby-Smith et al, (2002) comment on the choice the researcher has on remaining distanced from, or getting involved with, the material that is being researched; "The traditional assumption in science is that the researcher must maintain complete independence if there is to be any validity in the results produced. In social sciences, claims of the researcher's independence are harder to sustain" (p.43). Our own independence is harder to sustain in the context of this research and it is something that we do not strive for or see as possible. Reflexivity then is an important part of 
working with this dual identity. Alvesson and Skoldberg (2000) argue reflexivity occurs at the interface of different levels of interpretation. They talk of moving from data collecting, to preliminary interpretation guided by theory and cultural and implicit frames of reference and the researcher allowing the empirical material to 'inspire, develop and reshape theoretical ideas'. Further, they state that it is the theory that allows the researcher to find meaning in the empirical material and that the researcher's 'repertoire of interpretation' determines what is possible in terms of interpretation. The 'formula' for reflection is rich data plus breadth and depth in the repertoire of interpretation, enhancing the chance of 'empirically grounded imagination' (Alvesson and Skoldberg, 2000: p. 251). As we will show in the analysis below, we aspired to this through the use of a grounded theory approach and the lens of ANT as a sensitizing tool for the data and our interpretations.

\section{Analysis}

The research questions were explored through a qualitative methodology using ethnography and interviews as discussed. The data took the form of detailed typed up notes from our ethnographic diary, interview transcripts and other secondary data. The analysis of the data was approached inductively. Generally an inductive stance advocates that theory is the outcome of research. Bryman and Bell (2003, p.14) argue: "the process of induction involves drawing generalizable inferences out of observations". The process of analysing and interpreting the data was an iterative one that involved moving between the fieldwork and literature on different theoretical perspectives. Each informed the other.

Ethnography may be defined as both a qualitative research process and method (one conducts an ethnography) and product (the outcome of this process is an ethnography) whose aim is cultural interpretation. Merriam and Associates (2002) argue that for a qualitative study to be an ethnography, it must present a socio-cultural interpretation of the data, it is not 
enough to describe the cultural practices of a group; the researcher also depicts his or her understanding of the cultural meaning of the phenomenon (p. 237). ANT can be seen as a set of concepts or ideas which provide a sensitising tool for interpreting data (McBride, 2003). As such we used ANT as a theoretical concept which helped approach the data. In using this framework we asked these broad questions to explore the data: What were the processes involved in the construction of the learning community? What was the educator's role in the ELL? Let us first give an overview of some of the key concepts within ANT which helped us 'think with the data' (Cousin, 2007).

ANT was principally developed by three sociologists, Callon (1986), Latour (1987, 1990, 1992) and Law (1986a, 1986b, 1987) and looks at science and society as a series of 'networks' interacting. Latour (2005, p.61) states that a good ANT study is one that follows the actors and traces the social connections in new and interesting ways. Law (1996) uses Akrich's (1992) study of the technology transfer of briquettes in Sweden to Nicaragua as an exemplary actor-network study. There are two points that he refers to which are relevant to this paper which are; firstly, her work both assumes and explores the idea that building and maintaining networks is an uphill battle - that enrolment is precarious and secondly, networks are processes or achievements rather than relations or structures that are given in the order of things (Law 1996, p.3). Studies such as Akrich's detail the process of how a heterogeneous network, an actor-network, comes into being. This study incorporates many of these aspects with a particular focus on the enrolment process (the construction of the network), the network maintenance and understanding ELL as a network effect.

ANT theorists characterize actor-networks as heterogeneous networks. Entities gain their identity only through other identities, through interactive relations (Miettinen, 1999, p. 176). These interactive relations consist of heterogeneous materials, including human and nonhumans. Law proposes that the concept of actor-networks is a way of suggesting that society, 
organisations, agents and machines are effects generated in patterns of diverse materials that are not simply human (Law, 1992, p. 381). Law (1992) applies ANT to the diagnosis of science hypothesising that it is a process of heterogeneous engineering, in which bits and pieces from the social, the technical, the conceptual and the textual are fitted together, and so converted (or 'translated') into a set of equally heterogeneous scientific products. Law continues by noting that this is a radical claim because these networks are composed not only of people but also of machines, animals, texts or any other material (Law, 1992, p.381).

An actor-network is created or formed through the process of translation and all the actors are enrolled into a network by this process. Translation does not attempt to explain why a network exists; it is more interested in the infrastructure of actor-networks. Typically it has been used to show how artefacts become indispensable or not to the worlds in which they circulate, and to which they can contribute. The process of translation involves negotiations among human and non-human actors/actants which serve to define their interests and actions in the network. Typically there is a primary actor who (or which) aligns the interests of other actors within the actor-network and mobilizes them into forming the network. The relations are seen as network effects. Any actor- network, then is the effect, or result, of the connections that constitute it. For ANT there are no causes, only effects. There are no essences, only heterogeneous networks.

In tandem with ANT as a sensitizing tool, a number of themes emerged which led to us using a more systematic approach of template analysis as well as the lens of ANT. Template analysis refers to a particular way of thematically analysing qualitative data. The process involves a coding "template" which summarises themes identified as important in the data and organises them in a meaningful and useful manner. Themes are features which the researcher sees as relevant to the research question. Coding is the process of identifying themes in accounts and attaching labels (codes) to index them. We took an inductive approach and 
underwent iterations of modifying and applying the template, inserting new themes and deleting unwanted ones. This involved a process of prioritisation whilst trying to maintain openness towards the data and themes. King $(1998$, p.127) recognises the problems of when to stop the process of development arguing that this decision is always going to be unique to a particular project and a particular researcher. We made a pragmatic decision that we had reached an acceptable version of the template when we felt there were no relevant parts of the texts (ethnographic diary, LEAD forum posts, interview transcripts) that were uncoded.

Alongside this process we embarked on a systematic process similar to grounded theory's 'methodological package'. Once themes were identified a constant comparison method was followed broadly using these steps as set out by Glaser and Strauss (1967) (cited in Lincoln and Guba, 1985, p.339): comparing incidents applicable to each category, integrating categories and their properties, delimiting the theory, writing the theory. The themes undertook a process of data reduction and refinement and deviant cases were explored. Since the template is an aid to the interpretation and not an end in itself we used the theoretical frameworks in order to explore and explain the themes. Thus the interpretation evolved through the process of template analysis and the analytical lenses of ANT. We go on to present two aesthetic narratives in order to describe the lived experiences of delegates on LEAD which highlight some of the key themes that came from the data and ANT, that is enrolment, network maintenance and ELL as a network effect.

\section{Aesthetic narratives}

The narratives are based on real events but are written as amalgamations of events of LEAD combining our ethnographic observations, interviews, general conversations and emails. As such each one is presented as a composite character. The narratives are followed by a discussion which uses ANT as a lens for interpreting the accounts in order to explore the role 
of the educator as the primary actor in the construction and maintenance of the work and ELL as a network effect.

Insert narrative 1 and narrative 2

\section{Construction of the actor-network}

Latour (1992, p.243) is interested in "the complete chain along which competences and actions are distributed". It is through this understanding that the actor-network starts to develop and the social structures comprising both social and non-human entities are shaped and consolidated. The LEAD programme can be seen to be built as an actor-network made up of human and non-human actors. Human beings form a social network not because they interact with other human beings but because they interact with human beings and endless other materials too: "machines, architectures, clothes, texts - all contribute to the patterning of the social" (Law, 1992, p. 382). The construction of LEAD brings together multiple actors which through the process of translation. According to Callon (1986), the first moment of translation normally involves a primary actor defining the interests of other actors in ways that are consistent with their own interests. In this study the primary actor is two universities and a private training company. In narrative 1 we can see that the primary actor puts on a special 'bring a buddy' masterclass as one of the steps at constructing the next cohort. The primary actor works to convince other actors and negotiate their terms of involvement. A major activity is the recruitment process which involves the primary actor aligning the interests of intermediary actors (i.e. Brian) in order to reach the SMEs from which it desired to construct the actor-network. One of the main routes to identifying the ideal actors for the 
network is through recommendations from previous delegates for potential recruits onto the programme. This process is reliant on the social capital developed with the previous and current delegates inviting them to be ambassadors for the programme.

In ANT actors being enrolled into the network must pass through obligatory passage points; that is a point which anyone with a stake in the network would have to pass through in order to achieve their goals (Callon, 1986). In his analysis Fox (2005) suggests that people are enrolled by teachers and translated into learners with the teachers acting as Callon's (1986) obligatory points of passage. The role of the primary actor in the translation of the SME ownermanagers to LEAD delegates, and therefore learners echo this process. The primary actor, along with Brian (and other current delegates), establish themselves as the obligatory passage point between other actors, i.e. James and the other potential LEAD delegates. The application form and the group interview are also obligatory passage points and service both to enrol new actors (i.e. potential delegates) in to the network and to begin to align their interests, i.e. LEAD can help with the growth of the business and to help Brian punch through the brown paper back and get the holiday he wants. The recruitment process acts as an obligatory passage point by the universities and the private training company as the primary actor. The decision is made by the primary actor of that particular programme by looking at the application form and making a decision based on their interview, aligning the interests of other actors.

\section{Network maintenance}

The role of the primary actor, portrayed in narrative 2 by Ann, is key in the process of translation and the maintenance of the actor-network. However, the other delegates are integral to the learning within the actor-network and thus the maintenance. The role of the primary actor in this context is to enable the learning, which, by large, takes place between the delegates through peer learning. In narrative 2 , the delegates are feeding back their experiences of 
shadowing one another. The delegates see themselves as co-learners, who all have a valid contribution to make to the community. The delegates are willing to ask each other for help, to share knowledge and to admit they do not have all the answers. The sense of being "in the same boat", as Freddie identifies, helps to create trust which in turn helps ELL. Trust is widely accepted as an important enabler of knowledge-management processes (see Hildreth and Kimble, 2004). Within LEAD, trust between delegates is a factor in the generation of knowledge and ideas. A lot of the exchanges with one another are about practical aspects of running a small business. They often ask one another for advice or help with a need they have. Their experience, their conversations and knowledge lie at the very heart of the network. Knowledge is constructed and circulated between the delegates who have the shared practice of being SME leaders and LEAD delegates. LEAD was designed to embrace and exploit the shared knowledge of the members sharing their experience of running SMEs. This practice encourages what Brown and Duguid (2001) recognise as an important element of social learning, the free flow of ideas, and serves to strengthen the LEAD actor-network and stabilize the identities and align the interests of the actors. Part of this is the development of a shared experience which can be seen in the "LEAD lexicon" as Freddie points out. During the course of the programme, the delegates develop a shared history and set of practices which words and phrases relevant only to them are developed. This is part of their learning experience and the identity they share as delegates on the programme.

Each LEAD cohort is more than another community of business owners, such as a networking group. The pedagogy encourages the circulation of knowledge because the delegates are working with the primary actor in a process where their interests are being aligned and stabilized. This is an ongoing, active dynamic to the actor-network and one which the primary actor is constantly ensuring happens. This stabilization takes place through the learning interventions and providing spaces for the delegates to be able to speak with their fellow LEAD 
peers to address real life problems in a safe, confidential environment and in a constructive way. In this way the enablers are part of what Law (1996) calls maintenance work, stabilizing and aligning the interests of the actors.

\section{ELL as a network effect}

ANT can be used to tell stories of learning (see Verran, 1999, for example) which can help to understand learning as a network effect. Although it is not a learning theory as such Fox $(2000,2005)$ has used ANT to understand learning within a network and as a result of the network, a network effect. Specifically, Fox (2005) has looked at the role education establishments have on the consumption of learning. He states: "People are enrolled by teachers and translated into 'learners'; they form queues to buy books, get in line to join the ranks of the professions, become this or that professional identity, participate in an educated, criticalthinking democracy, enter, inhabit and participate in the public life of the nation, and produce and consume the culture" (2005, p.106). Fox (2005) shows how learning is a network effect but we propose ANT can also be used to understand how learning networks are constructed, or as Fox (2005) says, how actors are translated into learners. The owner-managers' own translation into LEAD delegates involves a construction of the identity of being a LEAD delegate. Something as mundane as a biscuit tin is part of this identity. At every learning intervention, the biscuit tin is present during coffee breaks and over lunch. It serves to align the identity of the owner-managers as LEAD delegates ('I am a LEAD delegate therefore I have LEAD biscuits'). Equally, the buildings where LEAD takes places is part of this identity and the delegates feel ownership and familiarity with the learning setting, as Freddie notes; " $A h$, my second home”.

It is recognised that owner-managers experience feelings of loneliness and isolation (see Pittaway et al, 2009) so becoming part of the leadership programme helps to alleviate these 
feelings with like-minded people. The data show that the motivation for the SMEs to join LEAD was to benefit their businesses and developing their leadership is part of this motivation. James tells us how he knows the business can get to the next level but isn't sure he has the skills to take it there. The delegates are nearly always at a cross-road in their businesses, wanting to grow it or change direction but feeling they lack the skill to manage this. Becoming part of the actor-network is an active experience and one which involves the stabilization of identities to that of LEAD delegate and subsequently, leader (this has been explored in more depth in Barnes et al, 2015; Smith, 2011). The fact that they are all owner-managers means that they understand and identify with each other's issues. Their experience (and identity) is part of this.

The delegates undergo a learning journey over the 10 months of participating in the programme, the actor-network. Their leadership learning is effective because they develop a shared history and space which provides the opportunities of leadership learning they ordinarily have limited access to or experience of. LEAD after all is a leadership programme so the content / activities / design / focus of the learning interventions is leadership and leadership development, largely through a participative pedagogy to enable peer learning. In short, why SMEs learn leadership through LEAD is because the actor-network provides them with the opportunities for peer learning and leadership development because it is designed to do just that. They learn because they are there for leadership development and engage with multiple opportunities they wouldn't have access to without the actor-network. These opportunities are a network effect. Following Fox's (2005) example of seeing the learner and the learning process in a distinctive way consistent with a process-oriented sociology, as a network effect, we argue that ELL is a network effect. The LEAD actor-network translates owner-managers into learners and leaders. Becoming delegates in turn develops their leadership capabilities and 
a shift in identity towards that of leaders, as Jane recognises: "We feel that we are leaders and that we could lead any business."

\section{Conclusions}

We have used ANT to conceptualise LEAD as an actor-work. Our analysis and findings have shown the importance of the primary actor, in this case, the educator, in aligning and mobilising the interests of other actors enrolling them in to the network. The

principle of generalized symmetry within ANT, i.e. the treatment of humans and non-humans as analytically equal, enables us to highlight the importance of such things as an application form, words that form the LEAD lexicon and the buildings where LEAD takes place.

Something as mundane as a biscuit tin serves to strengthen the identity and belonging to the LEAD actor-network. This insight adds to understanding of the processes involved in constructing and maintaining peer learning networks allowing humans and non-humans to have legitimacy and agency in this process. ELL is a network effect but it isn't passive. The participative pedagogy that underpins the design of the actor-network is integral to the learning experience. A key aspect of the ELL is the network maintenance and one which educators should be aware of, i.e. the learning won't happen just as a result of building the actor-network, the network needs constant maintenance.

We have seen that LEAD can have a positive impact on the health of the business in terms of 'hard' outputs such as business growth and 'soft' outputs such as work-life balance (Wren and Jones 2006, 2012; Barnes et al, 2015). As we have stated, ELL is an important aspect of small business survival and growth. Jones et al, (2012, p. 470) argue in the current economic climate, supporting the development needs of SME owner-managers could not be more imperative. Our paper shows the importance of ELL for owner-managers and how it can happen through careful alignment of interests and network maintenance. 
By framing ELL as a network effect we are using ANT as an emergent learning theory, something that has not been done to a great extent (see Fox, 2005; 2009). The conversion of the social and technical through translation can help us to think through ELL as a network effect. Our findings, however, are limited in this case to the context of ownermanagers participating in a leadership programme. Whilst we believe our findings are relevant to educational programmes per se (i.e. learning as a network effect), we do not seek to generalize. This is a limitation of our approach and could be an avenue for further research. ANT has been criticised for being descriptive rather than critical. When approached from the angle of deciding what to explain, Miettinen (1999) states that ANT faces the same problem as positivistic empiricism did: "How is it possible to decide what is important and essential and what is not without theoretical preconceptions?" (p. 181). The problem then is what counts as an actor? Even with the prescribed agnosticism the researcher has to select between actors in terms of their relevance, which relies on certain assumptions being made.

Translation does not attempt to explain why a network exists; it is more interested in the infrastructure of actor-networks. When building learning networks, the educator should know why they wish a network to exist. Perhaps an angle for future research could be to think about learning as a network effect linked to the aspirations of the educator (the link between the outcomes and the intended learning outcomes for example). An ANT reading could be applied to other contexts. We could challenge the view that may suggest learning is always a network effect; what about when learning networks don't work or fall apart or the desired learning has not been achieved? These are questions that could be taken on in future studies. 


\section{References}

Akrich, M. (1992) "The de-scription of technical objects", Bijker, W. and Law, J. (eds) in Shaping Technology, Building Society: Studies in Sociotechnical Change, Cambridge, Mass., MIT Press, pp 205-224.

Alvesson, M, and Skoldberg, K (2000) Reflexive Methodology: new vistas for qualitative research. London: Sage

Bagheri, A. and Pihie, Z.A.L. (2011), Entrepreneurial leadership: towards a model for learning and development. Human Resource Development International, 14(4), 447-463.

Barnes, S., Kempster, S. and Smith, S. (2015), LEADing Small Business: Business Growth through Leadership Development, Cheltenham, UK and Northampton, MA, USA: Edward Elgar Publishing.

Bosworth, D.L., Davies, R. and Wilson, R.A. (2002), 'Skills, high level work practices and enterprise performance', IER Research Report, University of Warwick.

Brown, J. S. and Duguid, P. (2001), 'Knowledge organization: a social-practice perspective', Organization Science, 12(2), 198 - 213.

Bryman, A. and Bell, E. (2003) Business Research Methods, Oxford, Oxford University Press.

Burgess, R.G. (1984) In the Field: An Introduction to Field Research, London, Allen and Unwin.

Callon, M. (1986), 'Some elements of a sociology of translation: domestication of the scallops and the fisherman of St. Brieuc Bay', in Law, J (ed), Power, Action and Belief: A New Sociology of Knowledge? London, Routledge.

Cousin, G. (2007) “Thinking with data”, Educational Developments, March 2007 Available at: http://www.seda.ac.uk/resources/files/publications_16_eddev8_1.pdf

Cox, C.J. and Cooper, C.L. (1989), 'The making of the British CEO: Childhood, work experience, personality and management style', The Academy of Management Executive, 3(3), 241-245.

Davies, J. and Easterby-Smith, M. (1984), 'Learning and developing from managerial work experience', Journal of Management Studies, 21(2), 169-183.

DeRue, D. S. and Ashford, S. J. (2010), 'Who will lead and who will follow? A social process of leadership identity construction in organizations', Academy of Management Review, 35, $627-647$.

Drath, W.H., McCauley, C.D., Palus, C.J., Van Velsor, E., O'Connor, P.M.G. and McGuire J.B. (2008), 'Direction, alignment, commitment: Toward a more integrative ontology of leadership', The Leadership Quarterly, 19(6), 635-653. 
Easterby-Smith, M., Thorpe, R. and Lowe, A. (2002) Management Research: An introduction, 2nd Edition. London, Sage.

Edwards, A. (2005) "Let"s get beyond community and practice: the many meanings of learning by participating", The Curriculum Journal, 16 (1), pp. $49-65$.

Fox, S. (2000), 'Communities of practice, Foucault and actor-network theory', Journal of Management Studies, 37(6), 854-67.

Fox, S. (2005), 'An actor-network critique of community in higher education: implications for networked learning'. Studies in Higher Education, 30(1), 95-110.

Fox, S. (2009), 'Contexts of teaching and learning: an actor-network view of the classroom', in Edwards, R., Biesta, G. and Thorpe, R. (eds), Rethinking Contexts for Learning and Teaching: Communities, Activities and Networks, Abingdon, Oxon, Routledge.

Geertz, C. (1973) The Interpretation of Cultures: Selected Essays, New York, Basic Books.

Glaser, B.G. and Strauss, A.L. (1967) The Discovery of Grounded Theory, Chicago, Aldine.

Gordon, I., Hamilton, E. and Jack, S. (2012), A study of a university-led entrepreneurship education programme for small business owner/managers In: Entrepreneurship and Regional Development. 24, 9-10, 767-805

Henley, A. (2012), Assessing the impact of leadership quality on SME performance. 35th Institute of Small Business and Entrepreneurship Conference, Dublin, Ireland, 07/11/2012 08/11/2012.

Hildreth, P. and Kimble, C. (2004) Knowledge Networks: Innovation Through Communities of Practice, Hershey, PA, Idea Group Publishing.

Janson, A. (2008), 'Extracting leadership knowledge from formative experiences', Leadership, 4(1), 73-94.

Jones, K., Sambrook, S., Henley, A., Norbury, H. 2012. Higher education engagement in leadership development: using autobiographical narrative to understand potential impact. Industry and Higher Education 26(6), 61-472.

Kempster, S. (2006), 'Leadership learning through lived experience: A process of apprenticeship?' Journal of Management and Organization, 12, 4-22.

Kempster, S. and Cope, J. (2010), 'Learning to lead in the entrepreneurial context', International Journal of Entrepreneurial Behaviour and Research, 16(1), 6-35.

Kempster, S., Smith, S. and Barnes, S. (2015), 'A review of entrepreneurial leadership learning: A three dimensional explanation that draws on human, social and institutional capitals', in C.M. Leitch and R.T Harrison (eds), Research Handbook on Entrepreneurship and Leadership, Cheltenham, UK and Northampton, MA, USA: Edward Elgar Publishing. 
King, N. (1998) “Template analysis", in Symon, G. and Cassell, C. (eds) Qualitative Methods and Analysis in Organizational Research: A Practical Guide, London, Sage, pp. 118-134.

Latour, B. (1987), Science in Action: How to Follow Scientists and Engineers Through Society, Cambridge, MA: Harvard University Press.

Latour, B. (1990), 'Drawing things together', in Lynch, M. and Woolgar, S. (eds), Representation in Scientific Practice, Cambridge, MA: MIT Press, 19-68.

Latour, B. (1992), 'Where are the missing masses? The sociology of a few mundane artifacts', in Bijker, W. and Law, J. (eds), Shaping Technology / Building Society Studies in Sociotechnological Change, Cambridge, MA: MIT Press, 225-258.

Latour, B. (2005) Reassembling the Social: An Introduction to Actor-Network Theory, Oxford, Oxford University Press.

Law, J. (1996), 'Traduction/Trahison: Notes on ANT', published by the Centre for Science Studies, Lancaster University, Lancaster LA1 4YN, at http://www.comp.lancs.ac.uk/sociology/papers/Law-Traduction-Trahison.pdf

Law, J. (1986a) Power, Action and Belief: a New Sociology of Knowledge?, London, Routledge.

Law, J. (1986b) “The heterogeneity of texts", in Callon, M., Law, J. and Rip, A. (eds), Mapping the Dynamics of Science and Technology, Basingstoke, Macmillan Press, pp. 67-83.

Law, J. (1987) "Technology and heterogenous engineering: the case of Portuguese expansion", in Bijker, W. E., Hughes, T. P. and Pinch, T. (eds), The Social Construction of Technological Systems, Cambridge, MA, MIT Press, pp. 111-134.

Lincoln, Y. S and E. Guba, G. (1985) Naturalistic Inquiry, Beverley Hills, Sage

McBride, N. (2003) "Actor-network theory and the adoption of mobile communications", Geography, 88 (4), pp. 266-276.

McCall, M.W. (2004), 'Leadership development through experience', Academy of Management Executive, 18(3), 127-30.

McCall, M.W., Lombardo, M.M. and Morrison, A. (1988), The Lessons of Experience, Lexington, MA: Lexington.

Merriam, S. B. and Associates (2002), Qualitative Research in Practice: Examples for Discussion and Analysis, San Francisco, CA, Jossey-Bass.

Miettinen, R. (1999), 'The riddle of things: activity theory and actor-network theory as approaches to studying innovations', Mind, Culture, and Activity, 6(3), 170-195.

Pittaway, L., Missing, C., Hudson, N. \& Maragh, D. 2009. "Entrepreneurial learning through action: a case study of the Six-Squared program", Action Learning: Research and Practice, $6: 3,265-288$ 
Smallbone, D., Kitching, J.,Blackburn, R. and Mosavi, S. (2015), 'Anchor institutions and small firms in the UK: A review of the literature on anchor institutions and their role in developing management and leadership skills in small firms', UKCES (UK Commission for Employment and Skills), available at: https://www.gov.uk/government/uploads/system/uploads/attachment_data/file/414390/Ancho r_institutions_and_small_firms.pdf

Smith, S. (2011), 'How do small business owner-managers learn leadership through networked learning?', in L. Dirckinck-Holmfeld, V. Hodgson and D. McConnell (eds), Exploring the Theory, Pedagogy and Practice of Networked Learning, New York: Springer, pp. 221-36.

Surie, G. \& Ashley, A. (2008), 'Integrating pragmatism and ethics in entrepreneurial leadership for sustainable value creation', Journal of Business Ethics, 81(1), 235-246

Vecchio, R.P. (2003), 'Entrepreneurship and leadership: common trends and common threads'. Human Resource Management Review, 13, 303-327.

Verran, H. (1999), 'Staying true to the laughter in a Nigerian classrooms', in Law, J. and Hassard, J. (eds), Actor-Network Theory and After, Blackwell, Oxford.

Wren, C. and Jones, J. (2006), 'Ex-Post evaluation of the LEAD programme', University of Newcastle Upon Tyne: Newcastle, available at:http://www.lums.ac.uk/leaddeval.

Wren, C. and Jones, J. (2012), 'Quantitative evaluation of the LEAD Programme, 2004-11', University of Newcastle Upon Tyne: Newcastle, available at:

http://www.ncl.ac.uk/nubs/research/publication/192709 


\section{Narrative 1}

Last week Brian had phoned to tell James about an up-coming masterclass, part of the leadership programme he was on called LEAD. James now finds himself reversing his car into a space at where this masterclass is being held. He is feeling nervous and adjusts his tie in his rear-view mirror. He thinks, "What am I doing here? How is this going to help me?" He has often thought that his business has so much more potential. Only last night he was saying to his wife that he feels like he is stuck in a brown paper bag and if he could just punch his way out of it, he knows the business will grow... and they will get that long overdue holiday. Before he has the chance to chicken out, Brian appears at the car window smiling, "Come on in, this is a 'bring a buddy' event and you are my buddy. Don't worry, you'll enjoy it".

After the masterclass, James and Brian are standing in the atrium having a cup of tea with about 50 other small business owners, many of whom are on the programme. The atmosphere is jovial, there is lots of talking and laughing. James did indeed enjoy the masterclass, there was certainly a lot of food for thought. Could he really give up two days a month for the next 10 months? He moots this to Brian who is quick to respond, "It isn't about giving up two days, honestly, my LEAD days have become very precious to me, I don't know what I'll do when it ends". Still sceptical, James dubiously picks up an application form.

A week later, James is back for a group interview. He had received a newsletter from the LEAD team telling him some of the positive changes the current delegates were making to their businesses and he filled the application form in and sent it off. And now he is at the next stage, the interview. Again, he is nervous and thinking about all the things he should be getting on with. The interview is with four other owner-managers of businesses and James is surprised at how open everyone is being. One of the others comments on how lonely it is running your own business, James agrees, certainly sometimes he feels very distant from his employees and he's sure his wife is sick of hearing about his business woes. During the interview, the course leader asks them all why they want to be on the programme, what they want from it and where they want their businesses to be in three years. The process is competitive, there are more people wanting to join than there are places available. "Right", James thinks, "I want this, I have got one chance at getting through this brown paper bag and growing the business". 


\section{Narrative 2}

A few months later, the whole cohort is together at the feedback from shadowing session. There is always a buzz in the air when the LEAD delegates are in; it is as if they are hungry for conversations with one another. The delegates have paired up and have spent time in each other's businesses, observing their pair in his or her own context, speaking to their staff and carrying out some mutually agreed mini projects. Many have arrived early, having taken advantage of getting a coffee and a biscuit from the ever present LEAD biscuit tin and seeing each other. Freddie walks in and joins those already there, taking a seat next to Jane, his shadowing peer. As he sits down, Jane hands him a cup of coffee, with a lot of milk, as he likes to take it. He thanks her, takes a biscuit from the LEAD biscuit tin and, noticing that his favourite ones are there, takes another for later on. He says "Ah, my second home! I'm really looking forward to hearing what everyone has to say about their shadowing experience, I've learnt so much, I wonder what the others did and how they got on. As we know, we're all in same boat after all!" Jane agrees.

The facilitator, Ann, motions them into the room where today's session will take place. "It's like herding cats", she thinks warmly as they take an age to settle down. "But this is what they are supposed to be doing, talking to one another." She hates to interrupt these valuable conversations but she knows they will genuinely enjoy today and get a lot from it.

An hour later, Freddie and Jane were first to present their reflections on their learning in a 7-minute burst followed by questions and answers. "Firstly," said Freddie, "it is such a privilege to be able to go into someone else's business. I found the whole experience enlightening."

"We both also observed that balance is key," said Freddie. "There needs to be consensus and the appropriate challenge with the use of open questions rather than people dominating discussions. We both observed others getting the balance wrong. Allied to this learning point is the importance of freedom of speech which requires 'coaching for extraordinary results'. I submit that this is a LEADism, a phrase for the LEAD lexicon," laughed Freddie.

"Neither of us were aware of our next learning point," noted Jane. "We feel that we are leaders and that we could lead any business." 